\title{
Bicycle helmet law does not deter cyclists in Finland
}

Radun, Igor

2018-10

Radun , I \& Olivier , J 2018 , ' Bicycle helmet law does not deter cyclists in Finland ' ,

Transportation Research. Part F: Traffic Psychology and Behaviour, vol. 58 , pp. 1087-1090

. https://doi.org/10.1016/j.trf.2018.06.022

http://hdl.handle.net/10138/310080

https://doi.org/10.1016/j.trf.2018.06.022

cc_by_nc_nd

acceptedVersion

Downloaded from Helda, University of Helsinki institutional repository.

This is an electronic reprint of the original article.

This reprint may differ from the original in pagination and typographic detail.

Please cite the original version. 


\section{Title: Bicycle helmet law does not deter cyclists in Finland}

Igor Radun, ${ }^{1,2, *}$ and Jake Olivier ${ }^{3}$

1 Department of Psychology and Logopedics, Faculty of Medicine, University of Helsinki, Helsinki, Finland

2 Stress Research Institute, Stockholm University, Stockholm, Sweden

3 School of Mathematics and Statistics, University of New South Wales, Australia

* Corresponding author

\section{Contact information:}

University researcher Igor Radun, Department of Psychology and Logopedics, Faculty of Medicine, P.O. Box 21, 00014 University of Helsinki, Finland; Ph.: +358 9 19129423; E-mail: igor.radun@helsinki.fi; twitter: https://twitter.com/Liikennepsykol1 Associate Professor Jake Olivier PhD AStat, School of Mathematics and Statistics The Red Centre, Room 2051, University of New South Wales Sydney NSW 2052; Ph: +61 29385 6656; E-mail: j.olivier@unsw.edu.au 


\section{Abstract}

Bicycle helmet legislation (BHL) in Finland went into effect in January 2003 and applies to cyclists of all ages. There are no mechanisms to fine cyclists riding without a helmet; however, helmet wearing rates are $64 \%$ in Helsinki and $42 \%$ across Finland. Our aim was to discuss possible effects of BHL on cycling in Finland. We used data from the 1998/1999, 2004/2005 and 2010/2011 Finnish National Travel Surveys. Data across three surveys suggest cycling has declined from before to after BHL. In a 2004/2005 survey, however, only $0.063 \%$ (95\% CI: $0.02-0.10 \%$ ) of responders identified helmet use as their most important obstacle to cycling. It is unlikely BHL is a causal factor in the downward trend in Finnish cycling. Lack of cycling infrastructure and concerns for safety are much more common reasons given.

Key words: Enforcement, Helmet, Bicycle, Surveys, Traffic law 
Radun, I., Olivier, J. (2018). Bicycle helmet law does not deter cyclists in Finland. Transportation Research

Part F: Traffic Psychology and Behaviour, 58, 1087-1090. https://doi.org/10.1016/j.trf.2018.06.022

\section{INTRODUCTION}

Bicycle helmet use has been shown to be an effective strategy for reducing head and face injury in a crash and the estimated benefit increases with the severity of injury (Attewell, Glase and McFadden 2001; Olivier and Creighton 2017; Thompson, Rivara and Thompson 2000). Some authors have been critical of bicycle helmet effectiveness studies while suggesting helmet use increases neck injury or rotational acceleration (Curnow, 2003); however, these hypotheses have not been supported by subsequent research (Olivier \& Creighton, 2017). Accordingly, 26 countries have introduced bicycle helmet legislation (BHL) in order to increase helmet use among cyclists (Esmaeilikia, Grzebieta and Olivier 2017). These laws differ in terms of the cyclist's age and level of enforcement.

The Finnish law went into effect in January 2003 and applies to cyclists of all ages. Surveys have indicated increases in helmet use in Helsinki (prevalence of $16 \%$ in $1993,40 \%$ in $2002,64 \%$ in 2016; City of Helsinki 2016; Figure 1) and in the whole of Finland (4\% in 1990, 22\% for 19962002, 42\% in 2016; Finnish Road Safety Council 2017; Figure 1) following the introduction of the helmet law. Increased helmet wearing is consistent with an effective helmet law; however, other factors such as fewer cyclists cannot be ruled out.

[Figure 1 near here]

There is an ongoing international debate regarding whether BHL reduces cycling (Robinson, 2006; Olivier et al, 2014). Cycling is considered a healthy activity (Johan et al. 2010) and there is concern the benefits of cycling will be lost if it is replaced with an inactive mode of transport (Adams and Hillman 2001). The impact of the Finnish helmet law on cycling has not previously been accessed in the literature. 
Radun, I., Olivier, J. (2018). Bicycle helmet law does not deter cyclists in Finland. Transportation Research

Part F: Traffic Psychology and Behaviour, 58, 1087-1090. https://doi.org/10.1016/j.trf.2018.06.022

The Finnish helmet law includes the qualifier yleensä which translates to either "usually" or "in general". The wording of the law has made typical enforcement methods difficult to implement and, in 2017, a repeal of the law was proposed, in part, due to the vague wording (Finnish Government 2017). The Government also believed the law would prove problematic for existing and future bicycle-share schemes and cited research suggesting that such laws deter cycling and thus supposedly reduce the health benefits of cycling.

The aim of this brief report is to discuss possible impact of the Finnish BHL on cycling. In particular, we examine trends in estimates of cycling exposure (distance and time travelled, number of trips) before and after BHL and reported obstacles to cycling in the year following BHL.

\section{METHODS}

We used data from the 1998/1999, 2004/2005 and 2010/2011 Finnish National Travel Surveys. These surveys involve Finns over the age of six years but exclude residents of Åland (Finnish Transport Agency 2002). Data were collected by telephone interview. The initial sample was drawn from the population register and included 18,250 responders in 1998/1999, 20,075 responders in $2004 / 2005$, and around 20,000 responders in 2010/201. Response rates were $64 \%, 65 \%$ and $56 \%$ for those years, respectively. Participants were chosen by stratified random sampling (e.g., sex, age and place of residence in the $2004 / 2005$ survey) with oversampling to ensure reliable results in low population density areas with large exposure variability. Sampling weights were estimated in accordance to the survey design to ensure the results are representative of the Finnish population. More information about the survey methodology can be found in the final reports for each survey available on the Finnish Transport Agency website (http://www.liikennevirasto.fi/tilastot/henkiloliikennetutkimus/julkaisut). 
Radun, I., Olivier, J. (2018). Bicycle helmet law does not deter cyclists in Finland. Transportation Research

Part F: Traffic Psychology and Behaviour, 58, 1087-1090. https://doi.org/10.1016/j.trf.2018.06.022

For all three surveys, we extracted aggregated data on distance travelled ( $\mathrm{km} /$ person/day), number of trips (trips/person/day), and time travelled (min/person/day) by bicycle from the PC-Axis table (HLT1KULK980410) on the Finnish Transport Agency webpage

(http://www.liikennevirasto.fi/tilastot/henkiloliikennetutkimus/itsepalveluanalyysit).

Additionally, as we had access to complete 2004/2005 survey data, we report results regarding questions concerning the reported primary obstacles to using various modes of transport, including cycling. Participants were asked to indicate the "most important obstacle or problem limiting travel by bicycle." Multiple responses were not allowed.

For our purposes, responses for the most important obstacle to cycling have been categorized as "no obstacles," "uncontrollable issues" (long distances, poor weather, old age, illness, injury, disability, cycling is slow), "miscellaneous" (no bicycle, bicycle broken, need to transport things, exercise makes you hot, laziness, self-comfort, other), "lack of infrastructure" (bicycle parking, lack of cycling paths/lanes, road crossings, signage for walking/cycling), "concerns for safety" (risk of injury, lack of safety, bicycle theft), and "helmet". This categorization was similar to a recent publication on obstacles to cycling (Olivier, Boufous and Grzebieta 2016).

\section{RESULTS}

Cycling exposure data for each survey are given in Table 1 . The number of daily bike trips per person decreased by $23 \%$ and kilometres travelled decreased by $21 \%$ from the $1998 / 1999$ to the 2010/2011 surveys. The results from the 2004/2005 survey are consistent with the downward trend.

[Table 1 near here] 
Radun, I., Olivier, J. (2018). Bicycle helmet law does not deter cyclists in Finland. Transportation Research

Part F: Traffic Psychology and Behaviour, 58, 1087-1090. https://doi.org/10.1016/j.trf.2018.06.022

The estimated proportion of the Finnish population by each important obstacle to cycling from the $2004 / 2005$ survey is given in Figure 1. Only nine out of the 13,386 people surveyed $(0.063 \%, 95 \%$ CI: $0.02-0.10 \%$ ), indicated helmet use to be their most important obstacle. Most responders (58\%, 95\% CI: $57.3-59.0 \%$ ) reported no obstacles, but $4 \%$ and $2 \%$ cited lack of infrastructure and concerns for safety, respectively (infrastructure, 95\% CI: 3.4-4.1\%; safety, 95\% CI: $1.9-2.3 \%$ ). Curiously, although Finland has an average July temperature of $13-17^{\circ} \mathrm{C}$, "exercise makes you hot" $(n=12)$ was a more common response than helmet use.

[Figure 2 near here]

\section{DISCUSSION}

Cycling in Finland has steadily declined from the late 1990's to the early 2010's. Those opposed to helmet legislation often stress that cycling has declined in Finland while suggesting the helmet law was a causal factor. However, this claim is unsupported by the self-reported most important obstacles to cycling derived from the 2004/2005 National Travel Survey.

Immediately following the helmet law in Finland, an estimated $42 \%$ of Finns aged six years and older reported that they were deterred from cycling, but only $0.063 \%$ of all responders gave helmet use as the most important reason for not cycling. This result is consistent with findings in Australia (Olivier, Boufous and Grzebieta 2016) and Canada (Dennis et al, 2010; Macpherson, Parkin and To 2001), while a US study found mixed results (Kraemer 2016).

If the Finnish law was not responsible for the decline in cycling, there are other explanations to consider. One report found declines in both walking and cycling across all ages with the largest decline among 15-17-year-olds (Finnish Transport Agency 2002). During the study period, there were increases in moped and microcar travel for this age group (Finnish Transport Agency 2002). 
Radun, I., Olivier, J. (2018). Bicycle helmet law does not deter cyclists in Finland. Transportation Research

Part F: Traffic Psychology and Behaviour, 58, 1087-1090. https://doi.org/10.1016/j.trf.2018.06.022

On the other hand, the number of passenger cars in Finland increased by $20 \%$ between 1998 and 2005 and by 47\% in 2010 (Statistics Finland 2017). Similar declines in cycling have been observed in European countries without BHL, such as the UK and Denmark (Cycling Embassy of Denmark 2010; United Kingdom Department of Transport 1999).

There are important limitations to this study. The self-reported reasons for not cycling may be inaccurate. However, the number of helmet responses would need to increase many fold for helmet legislation to be seen as a major barrier to cycling from this data. The accuracy of cycling exposure estimates is unclear as unit-record data were not available in the PC-Axis table and therefore standard error estimates could not be calculated. The surveys were conducted on only three occasions with only one pre-legislation observation. Therefore, it is unclear whether the reduction in cycling was part of an existing trend.

Regardless of possible alternative explanations, it would appear the Finnish bicycle helmet law is an unlikely reason for the reductions in cycling observed. The available Finnish data suggest other factors, such as cycling infrastructure, are more important obstacles to those who refrain from cycling.

\section{Acknowledgments}

Jake Olivier is supported by the Swedish Transport Administration (Trafikverket) and Igor Radun by the Finnish Crash Data Institute (OTI), Finland. The funders had no role in the conception, design, analysis, interpretation of data, or writing of this article. The authors thank Professor Emeritus Barry Pless and Professor Alison Macpherson for their valuable comments and suggestions on an earlier draft of this paper. 


\section{REFERENCES}

Adams J, Hillman M. The risk compensation theory and bicycle helmets. Inj Prev 2001;7: 89-91.

Attewell RG, Glase K, McFadden M. Bicycle helmet efficacy: A meta-analysis. Accid Anal Prev 2001;33:345-52.

City of Helsinki (2016). Pyöräliikenteen laskennat Helsingissä 2016 [Cycling statistics in Helsinki 2016]. Available at: http://www.hel.fi/hel2/ksv/julkaisut/los_2016-5.pdf (accessed 6.11.17)

Curnow WJ. The efficacy of bicycle helmets against brain injury. Accid Anal Prev 2003;35: 287292.

Cycling Embassy of Denmark (2010). Bicycle statistics from Denmark. Available at: http://www.cycling-embassy.dk/wp-content/uploads/2010/03/Bicycle-statistics-fromDenmark.pdf (accessed 6.11.17)

Dennis J, Potter B, Ramsay T, Zarychanksi R. The effects of provincial bicycle helmet legislation on helmet use and bicycle ridership in Canada. Inj Prev 2010;16:219-224.

Esmaeilikia M, Grzebieta R, Olivier J. A systematic Review on the Effects of Bicycle Helmet Legislation on Cycling. 2017 International Cycling Safety Conference Proceedings, Davis, USA.

Finnish Government. Hallituksen esitys eduskunnalle tieliikennelaiksi ja eräiksi siihen liittyviksi laeiksi [The Government's proposal to the Parliament regarding road traffic law and some related 
Radun, I., Olivier, J. (2018). Bicycle helmet law does not deter cyclists in Finland. Transportation Research

Part F: Traffic Psychology and Behaviour, 58, 1087-1090. https://doi.org/10.1016/j.trf.2018.06.022

laws]. 2017. Available at:

https://www.lausuntopalvelu.fi/FI/Proposal/DownloadProposalAttachment?attachmentId=3010 (accessed 6.11.17)

Finnish Road Safety Council Available - Liikenneturva. Liikennekäyttäytymisen seuranta [Traffic behavior statistics]. 2017. Available at:

https://www.liikenneturva.fi/sites/default/files/materiaalit/Ajankohtaista/liikennekayttaytymisen_se uranta_netti.pdf(accessed 6.11.17)

Finnish Transport Agency, Transport Planning. National Travel Survey 2010-2011 [In Finnish, with English abstract]. Helsinki, 2012. Available at:

http://www2.liikennevirasto.fi/julkaisut/pdf3/lr_2012_henkiloliikennetutkimus_web.pdf (accessed $6.11 .17)$

Hernan MA, Clayton D, Keiding N. The Simpson's paradox unraveled. Int J Epidemiol $2011 ; 40: 780-785$.

Johan H, Boogaard H, Nijland H, Hoek G. Do the health benefits of cycling outweigh the risks? Environ Health Perspect 2010; 118:1109-16.

Kraemer, J.D. Helmet Laws, Helmet Use, and Bicycle Ridership. J Adolesc Health 2016; 59: 338344.

Macpherson AK, Parkin PC, To TM. Mandatory helmet legislation and children's exposure to cycling. Inj Prev 2001; 7:228-30. 
Olivier J, Creighton P. Bicycle injuries and helmet use: A systematic review and meta-analysis Int J Epidem, 2017; 46:278-292.

Olivier J, Boufous S, Grzebieta R. No strong evidence bicycle helmet legislation deters cycling. Med J Austral 2016; 205:54-55.

Olivier J, Wang J, Walter S, Grzebieta R. Anti-helmet arguments: Lies, damned lies and flawed statistics. J Australas Coll Road Saf 2014; 25:10-23.,

Robinson DL. No clear evidence from countries that have enforced the wearing of helmets. $B M J$ $2006 ; 332: 722-725$.

Statistics Finland. Motor vehicle stock. 2017. Available at: http://www.stat.fi/til/mkan/tau_en.html (accessed 27.04.17)

Thompson DC, Rivara FP, Thompson R. Helmets for preventing head and facial injuries in bicyclists. Cochrane Database Syst Rev 2000:CD001855.

United Kingdom Department of Transport. (1999). Road Accidents Great Britain 1998: The Casualty Report. 
Radun, I., Olivier, J. (2018). Bicycle helmet law does not deter cyclists in Finland. Transportation Research

Part F: Traffic Psychology and Behaviour, 58, 1087-1090. https://doi.org/10.1016/j.trf.2018.06.022

Table 1: Estimates of cycling exposure in Finland (1998/99, 2004/05, 2010/11)

\begin{tabular}{|c|c|c|c|}
\hline \multirow[b]{2}{*}{ Survey Years } & \multicolumn{3}{|c|}{ Cycling Exposure+ } \\
\hline & Distance & Time & Trips \\
\hline \multirow[t]{2}{*}{ 1998/1999 } & 0.92 & 6.0 & 0.31 \\
\hline & lmet law 1 & Januar & 2003 \\
\hline $2004 / 2005$ & 0.84 & 4.7 & 0.27 \\
\hline 2010/2011 & 0.73 & 3.8 & 0.24 \\
\hline
\end{tabular}

+ Cycling exposure measured in kilometres, minutes and number of trips per person per day 


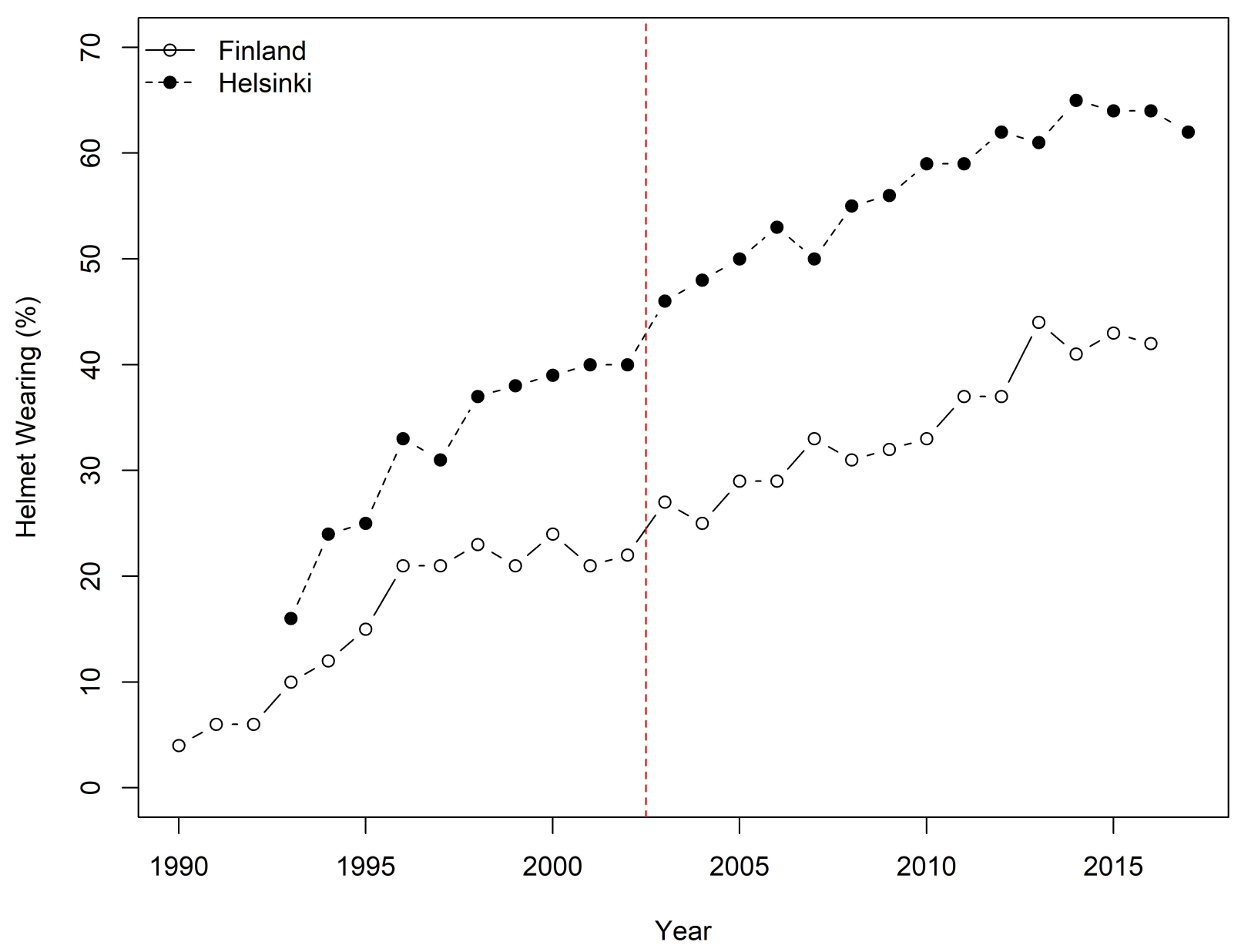

Figure 1. Prevalence of helmet use in Helsinki (Data supplied by City of Helsinki) and whole Finland (Finnish Road Safety Council, 2017). 
Radun, I., Olivier, J. (2018). Bicycle helmet law does not deter cyclists in Finland. Transportation Research

Part F: Traffic Psychology and Behaviour, 58, 1087-1090. https://doi.org/10.1016/j.trf.2018.06.022

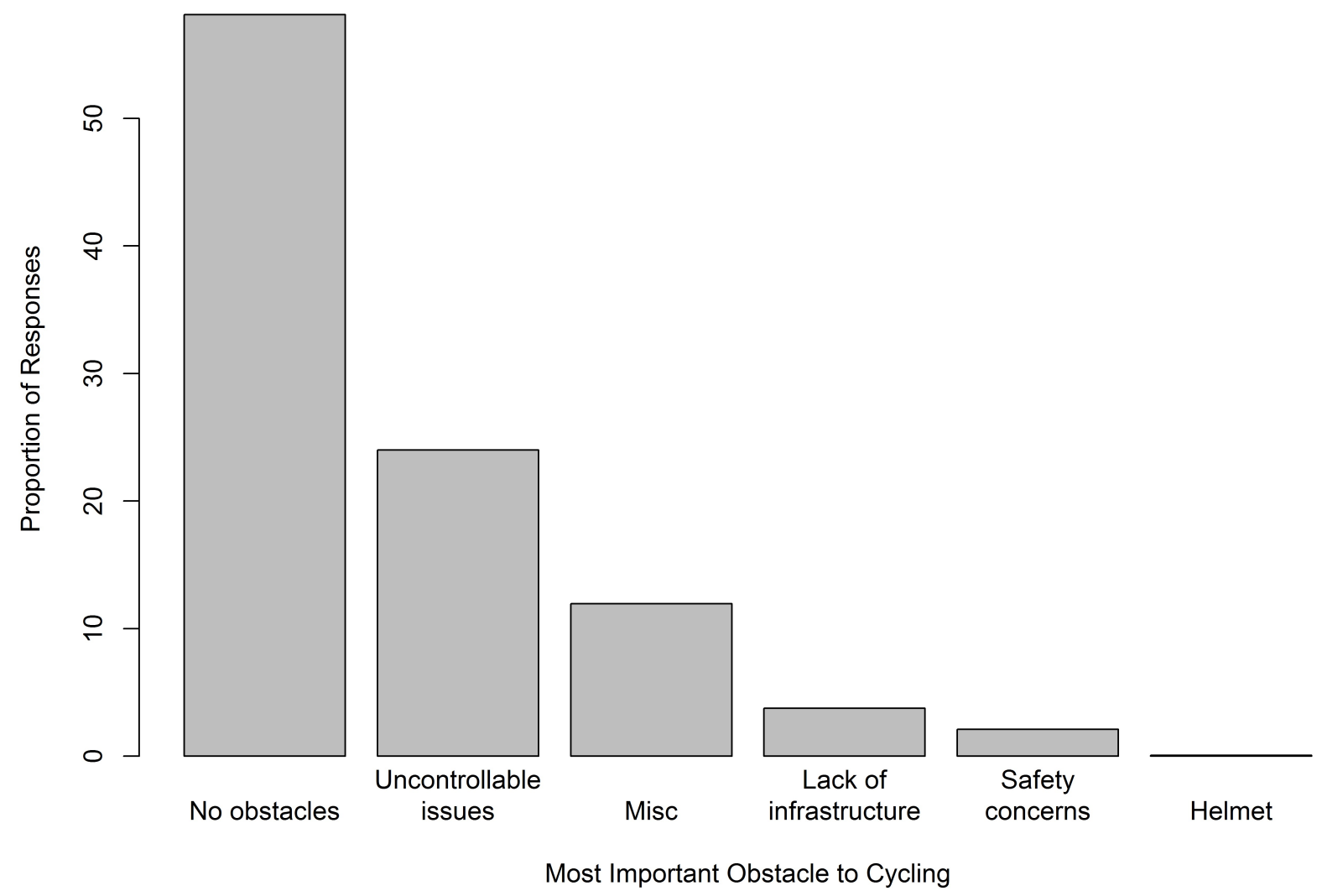

Figure 2. Proportions of responses for most important obstacle to cycling for Finnish population (6+ years) 